\title{
EFFECTS OF CURING TIME ON THE PERFORMANCE OF VOLCANIC SCORIA-BASED BINDER CONCRETES
}

\begin{abstract}
A. M. al-SWAIDANI ${ }^{1}$
The objective of the presented paper is to investigate the performance of concrete containing volcanic scoria as cement replacement after 7, 28, 90, and 180 days curing. Five performance indicators have been studied. Compressive strength, water permeability, porosity, chloride penetrability, and reinforcement corrosion resistance have all been evaluated. Concrete specimens were produced with replacement levels ranging from 10 to $35 \%$. Test results revealed that curing time had a large influence on all the examined performance indicators of scoria-based concrete. Water permeability, porosity, and chloride penetrability of scoria-based concrete mixes were much lower than that of plain concrete. Concretes produced with scoria-based binders also decelerated rebar corrosion, particularly after longer curing times. Furthermore, an estimation equation has been developed by the authors to predict the studied performance indicators, focusing on the curing time and the replacement level of volcanic scoria. SEM/EDX analysis has been reported as well.
\end{abstract}

Key words: Curing time, Water permeability, Porosity, Chloride penetrability, Corrosion resistance, Binders, Volcanic scoria.

\section{INTRODUCTION}

Natural pozzolan is commonly used as a substitute for Portland cement because of its ecological, economical, and performance-related advantageous properties [1-8]. However, its use is often associated with shortcomings, such as the need for longer moist-curing and a reduction in strength at early ages. The country of Syria has large areas of high volcanic importance; more than $30000 \mathrm{~km}^{2}$ of the country is covered by Tertiary and Quaternary-age volcanic rocks [9], among which volcanic scoria occupies a high volume, with estimated reserves of about three-quarters of a billion ton [10]. However, their potential use in making concrete is not well established. The cement produced in the country is almost

\footnotetext{
${ }^{1}$ Assistant Professor \& Vice-Dean, ${ }^{1}$ Faculty of Architectural Engineering, Arab International University (AIU), Damascus, Syria,(aydlswaidan@gmail.com; a-swaidani@aiu.edu.sy)
} 
all CEM I, although the addition of natural pozzolan (of up to 5\%) was frequently used in most local cement plants. Hence, less than 300000 tonnes of these pozzolans are exploited annually (the annual production of Portland cement in Syria is about 6 million tonnes) [11]. It is widely accepted that any increase in the performance of reinforced concrete structures increases the sustainability of the construction industry. One of the most effective approaches could be to substitute pozzolans for a portion of Portland cement. Concrete strength is commonly considered its most valuable property, although, in many practical cases, other characteristics such as durability and permeability may in fact be more important [12].

Chloride-induced corrosion is currently considered to be the most serious deterioration mechanism for reinforced concrete structures. Chloride can penetrate concrete from external sources or be present in the mix constituents [13]. Corrosion of reinforcing steel is an important problem facing the construction sector in Syria, especially in industrial and marine environments. A lot of RC structures have suffered from this phenomenon, which significantly shortened their service lives.

The work presented in this paper reports a part of the first detailed research in the country to investigate the potential utilization of volcanic scoria as cement replacement in producing Portland-pozzolan cements, and its effects on the performance of mortar and concrete. In this study, in order to investigate the influence of curing time on various performance indicators, four curing times of 7, 28, 90, and 180 days have been assessed. Compressive strength development, water permeability, porosity, chloride penetrability, and corrosion resistance of reinforcement embedded in the concrete containing scoriabased cements have been investigated.

The study is of particular importance not only for the country but also for other countries of similar geology, e.g. Harrat Al-Shaam, a volcanic field covering a total area of some $45000 \mathrm{~km}^{2}$, a third of which is located in Syria (the rest covers parts of Jordan and Saudi Arabia).

\section{MATERIALS AND METHODS}

\subsection{Materials}

The volcanic scoria used in the experiments was quarried from the Dirat-at-Tulul site, located about 70 $\mathrm{km}$ southeast of Damascus, as shown in Fig. 1. Thin sections of the investigated scoria are shown in Fig. 2. The chemical analysis of scoria used in the study is summarized in Table 1. Seven binder samples were prepared in accordance with EN 197-1; one plain Portland cement CEM I (control), three CEM II/A-P 
samples with three replacement levels $(10,15$, and 20\%), and three CEM II/B-P samples with three replacement levels $(25,30,35 \%)$, respectively. Five percent of gypsum was added to all the binder samples. The clinker was obtained from the Adra Cement Plant in Damascus, Syria. Chemical analysis of the clinker and gypsum is shown in Table 1. All samples were interground by a laboratory grinding mill to a Blaine fineness of $3200 \pm 50 \mathrm{~cm}^{2} / \mathrm{g}$. CEM I (the control sample) was designated as C1/CEM I, whereas scoria-based binders were designated according to their percentage replacement levels. For instance, $\mathrm{C} 2 / 10 \%$ and $\mathrm{C} 7 / 35 \%$ refer to the binders containing $10 \%$ and $35 \%$ of volcanic scoria, respectively.

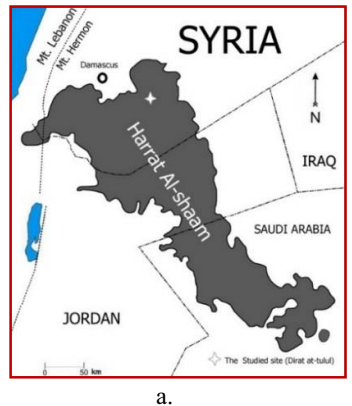

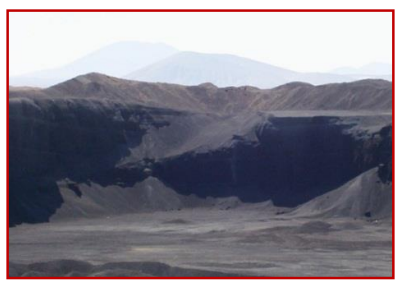

b.

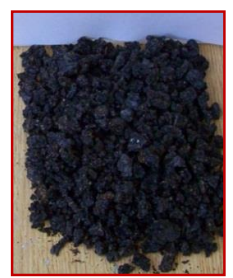

c.

Fig. 1. Map of Harrat Al-Shaam, photos of the studied site and the used scoria aggregate. a) Map of the volcanic area "Harrat Al-Shaam" and the studied site ; b) The studied scoria quarry, some volcanic scoria cones are shown behind ; c) The studied scoria aggregate.

Seven concrete mixes have been prepared using a grading of aggregate mixtures kept constant for all concrete mixes tested. Aggregates used in the study consisted of crushed dolomite with natural sand added. Chemical composition of the aggregates is illustrated in Table 1 . Their quantities in $1 \mathrm{~m}^{3}$ concrete mix based on oven-dry conditions were as follows: $565.5 \mathrm{~kg}$ of coarse aggregate, $565.5 \mathrm{~kg}$ of medium-size aggregate, $447.5 \mathrm{~kg}$ of crushed stone sand, and $286.5 \mathrm{~kg}$ of natural sand. All concrete mixes were designed to have a water-cementitious materials ratio of 0.6 and a slump of $150 \pm 20 \mathrm{~mm}$. No chemical admixture was added. Concrete cubes (150 $\mathrm{mm})$, concrete cylinders $(75 \mathrm{~mm} \times 150 \mathrm{~mm})$ and concrete cylinders $(100 \mathrm{~mm} \times 200 \mathrm{~mm})$ were cast in order to determine both compressive strength and water permeability, evaluation of the concrete porosity, and the penetrability of chloride ions, respectively. In addition, the reinforced concrete specimen for the accelerated corrosion tests was a $100 \mathrm{~mm} \times 200 \mathrm{~mm}$ concrete cylinder in which $12 \mathrm{~mm}$ diameter steel bar was centrally embedded. It was placed into the concrete cylinder so that its end was at least $45 \mathrm{~mm}$ from the bottom of the cylinder, and it was coated with epoxy at the exit point of the concrete cylinder in order to eliminate crevice corrosion at these locations. 


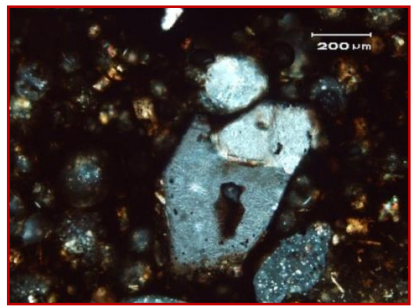

a.

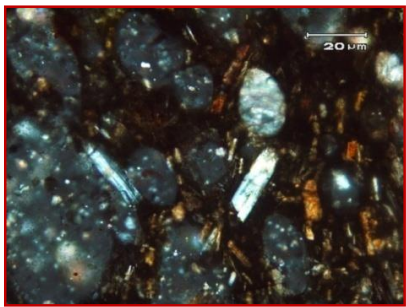

b.

Fig. 2. Thin sections of the scoria. a). Microphenocryst of Olivine in volcanic glass matrix with vesicles, some of which are filled with white minerals. b). Microphenocrysts of elongated plagioclase in volcanic glass matrix with vesicles, some of which are filled with white minerals.

Table 1. Chemical composition of the used materials

\begin{tabular}{|c|c|c|c|c|c|}
\hline \multirow{2}{*}{$\begin{array}{c}\text { Chemical composition } \\
\text { (by mass, \%) }\end{array}$} & Scoria & Clinker & Gypsum & Dolomite aggregate & Natural sand \\
\cline { 2 - 6 } & 46.52 & 21.30 & 0.90 & 0.42 & 93.39 \\
\hline $\mathrm{SiO}_{2}$ & 42.22 & - & - & - & - \\
\hline $\mathrm{SiO}_{2 \text { (reactive) }}$ & 13.00 & 4.84 & 0.07 & 0.38 & 0.57 \\
\hline $\mathrm{Al}_{2} \mathrm{O}_{3}$ & 11.40 & 3.99 & 0.10 & 0.10 & 0.24 \\
\hline $\mathrm{Fe}_{2} \mathrm{O}_{3}$ & 10.10 & 65.05 & 32.23 & 31.40 & 1.70 \\
\hline $\mathrm{CaO}$ & - & 2.1 & - & - & 0.20 \\
\hline $\mathrm{CaO}$ & 9.11 & 1.81 & 0.20 & 20.46 & 1.15 \\
\hline $\mathrm{MgO}_{\mathrm{SgO}}$ & 0.27 & 0.25 & 45.29 & 0.18 & 2.52 \\
\hline $\mathrm{SO}_{3}$ & 2.58 & - & 21.15 & 46.48 & 0.06 \\
\hline Loss on ignition & 2.14 & 0.60 & - & 0.06 & 0.05 \\
\hline $\mathrm{Na}_{2} \mathrm{O}$ & 0.77 & 0.28 & - & 0.30 & 0.017 \\
\hline $\mathrm{K}_{2} \mathrm{O}$ & $<0.1$ & 0.05 & - & 0.021 & \\
\hline $\mathrm{Cl}^{-}$ & 79 (at 7 days) & & & & \\
\hline Pozzolan activity index \\
\hline $\mathrm{ASTM} \mathrm{C} 618]$
\end{tabular}

\subsection{Methods}

The compressive strength development was determined on $150 \mathrm{~mm}$ cubic concrete specimens, in accordance with ISO 4012, at ages of 7, 28, 90, and 180 days cure time. Concrete permeability measured in terms of depth of water penetration was carried out as per the standard EN 12390-8, and the results shown in this paper are the average calculated penetration depth. Porosity measurements were conducted using the vacuum saturation method in accordance with RILEM CPC 11.3 and the average of three results 
was reported. The Rapid chloride penetrability (RCP) test was conducted in accordance with ASTM C 1202. The set-up of the RCP test is illustrated in Fig. 3. Three cylindrical specimens of each concrete mix were tested after 7, 28, 90, and 180 days curing.

A rapid corrosion test was used to compare the corrosion performance of concretes containing binders. Similar techniques with minor differences were reported by other researchers [14-22]. The corrosion process was initiated by impressing a relatively high anodic potential of $12 \mathrm{~V}$ to accelerate action. Fig. 4 shows a schematic representation of the experimental setup for the accelerated corrosion test. The specimen was monitored periodically to note the length of time it took for corrosion cracks to appear on the specimen surface. The current readings with time were recorded at 3-4 hour intervals. Three specimens from each concrete mix were tested after 7, 28, 90, and 180 days curing.

\section{RESULTS AND DISCUSSION}

\subsection{Compressive strength development}

The results of the compressive strength development tests are plotted in Fig. 5. As expected, the compressive strength of the concrete increased with curing time. Plain cement concrete specimens show a higher compressive strength at any age when compared to scoria-based binder concretes. This decrease in strength of scoria-based concretes was more pronounced at early ages, and increased with the percentage of volcanic scoria. The compressive strength at 7 days cure time decreased from 24.9 to 16.0 MPa when CEM I and CEM II/B-P with 35\% of scoria were used, respectively. This could be explained by i) the slow speed of the pozzolanic reaction between the glassy phase in scoria and the calcium hydroxide released during cement hydration [23], and ii) the dilution effect [24]. However, due to the continuation of the pozzolanic reaction and the formation of a secondary C-S-H, a greater degree of hydration was achieved, resulting in strengths (after 90 days of curing) which were comparable to those of CEM I specimens. 


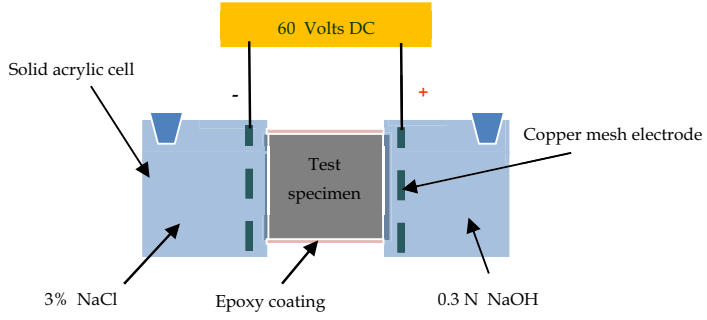

a.

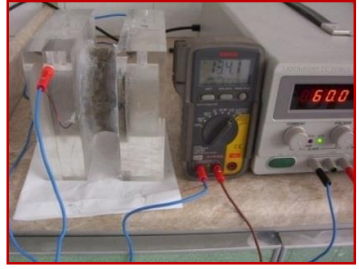

b.

Fig. 3. Experimental setup of rapid chloride penetration test. a) Schematic representation of experimental setup of rapid chloride penetration test. b) View of experimental setup (one of current readings for $\mathrm{C} 3 / 15 \%$ specimen).

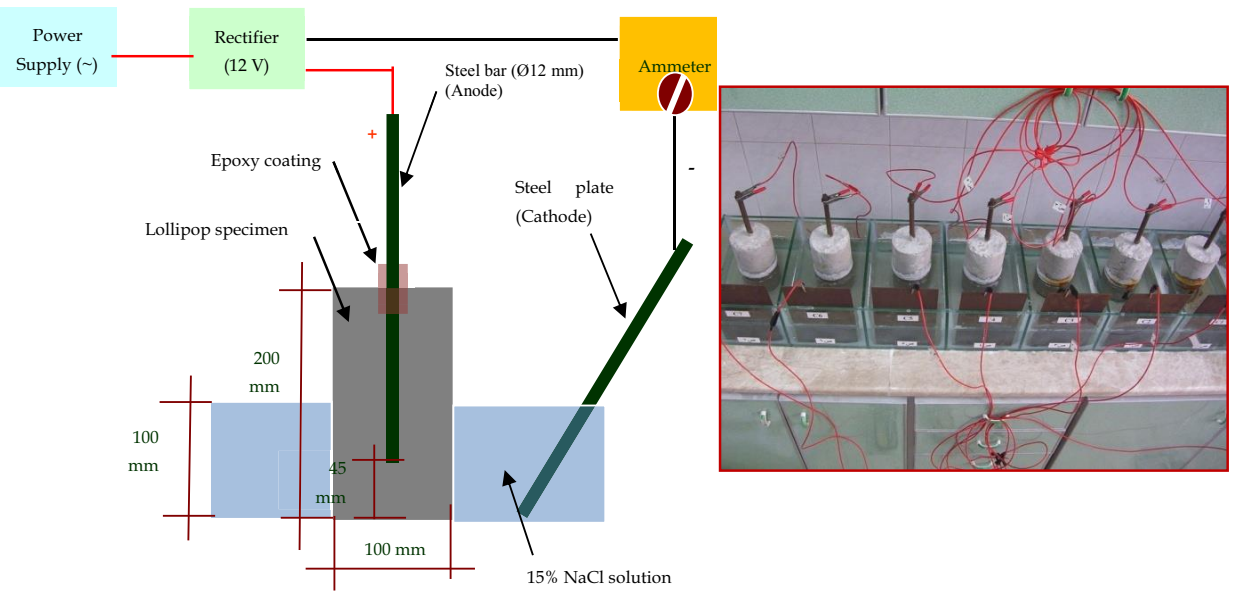

a.

b.

Fig. 4. Schematic representation \& view of experimental setup for the accelerated corrosion test. a) Setup for the accelerated corrosion test. b) View of 28 days-cured concrete specimens after 4 days of impressing $12 \mathrm{~V}$. potential.

\subsection{Water permeability}

Water penetration depth can be considered as an indication of permeable and impermeable concrete [12]. A depth of less than $50 \mathrm{~mm}$ classifies the concrete as impermeable and a depth of less than $30 \mathrm{~mm}$ as impermeable under aggressive conditions [12]. Fig. 6 shows the water penetration depth test results for all binder types. Concretes containing scoria-based binders are supposed to have lower permeability than plain Portland cement. However, in the results observed, it can be seen that after 7 days curing water 
penetration depths of CEM II/A-P cements (containing 6-20\% scoria) were higher than that of CEM I. Increasing the moist-curing period of concrete from 28 to 90 days reduced water penetration depths of all concretes by a factor ranging from 2.11 to 3.03 for concretes containing scoria-based cements, and a lower factor of 1.44 for plain Portland cement concrete. This result is in favorable agreement with the findings in existing literature [12].

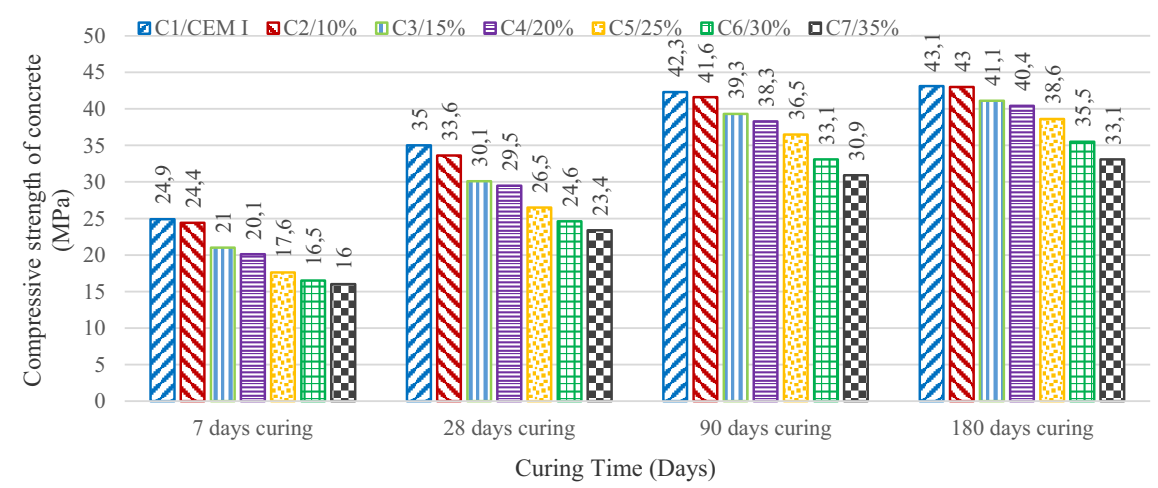

Fig. 5. Compressive strengths of different concretes at 7, 28, 90, and 180 days curing.

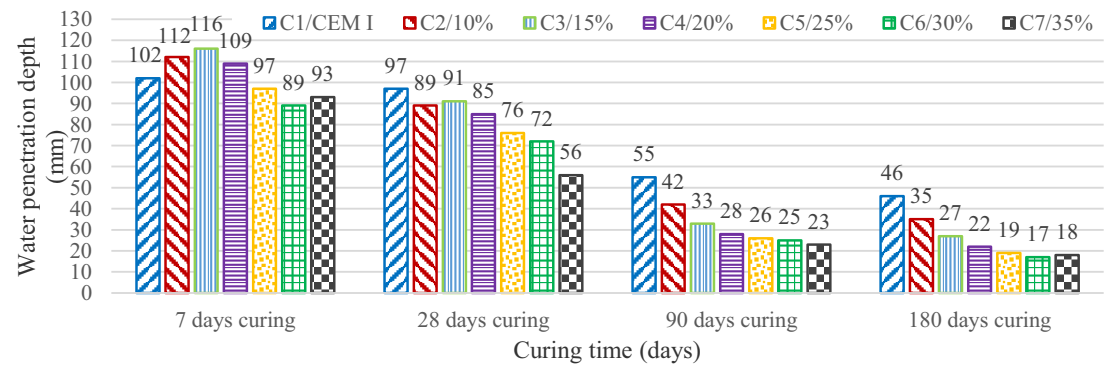

Fig. 6. Water penetration depths in different concretes cured for 7, 28, 90, and 180 days.

None of the concrete samples were found to be impermeable after 28 days curing, though all samples containing scoria-based binders can be considered impermeable after 90 days curing. Concrete samples containing binders with scoria content ranging from 20 to 35\% can be considered (after 90 days cure time) as impermeable even under aggressive conditions, according to [12]. However, the samples containing $15 \% \& 20 \%$ volcanic scoria needed 180 days curing to achieve this kind of impermeability. 


\subsection{Porosity}

Porosity of concretes containing different levels of volcanic scoria at various curing times is presented in Fig. 7. Porosity of all mixes decreased with curing time. As volcanic scoria became incorporated, porosity decreased significantly. Porosity of the concrete samples containing CEM II/P demonstrated much lower numbers when compared to the plain concrete. The rate of the decrease in porosity was faster for volcanic scoria-containing concretes, comparing to the plain concrete. The reduction in porosity could be attributed to the pozzolanic reaction between the glassy phase in volcanic scoria and the $\mathrm{CH}$ liberated from the hydration of $\mathrm{C}_{3} \mathrm{~S} \& \mathrm{C}_{2} \mathrm{~S}[8]$.

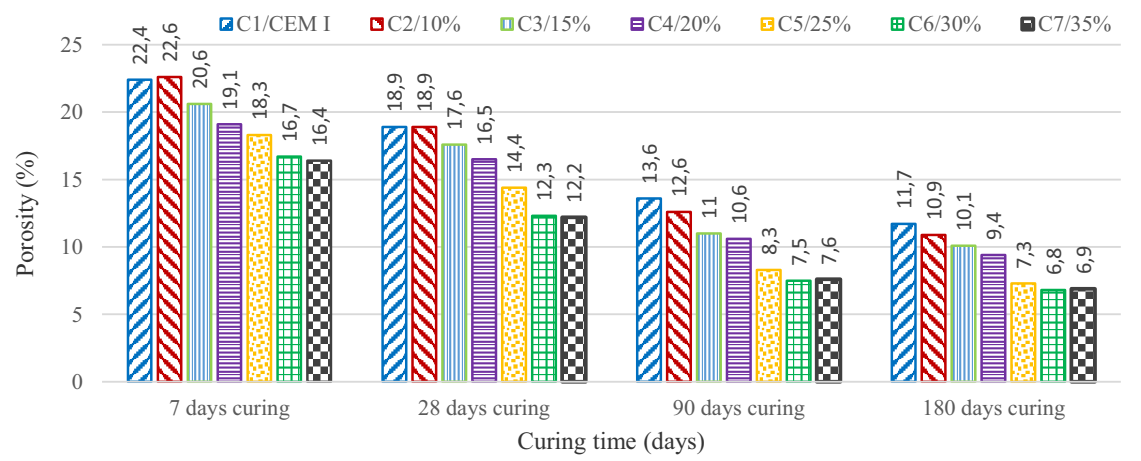

Fig. 7. porosity of concretes with different levels of volcanic scoria after 7, 28, 90, and 180 days curing.

\subsection{Rapid chloride penetrability}

From the Rapid chloride penetrability data, as illustrated in Fig. 8, it should be noted that the CEM Ibased concrete permitted almost 2 or 3 times more the coulombs charge, compared to the concrete containing CEM II/B, in spite of the fact that all samples were made with similar cementitious and water content. None of the concretes having a total charge passed less than 2000 coulombs after 7 or 28 days curing. This expected result may be due to the high $\mathrm{w} / \mathrm{cm}$ ratio. However, the samples containing CEM II/B-P with scoria contents of 25,30 , and $35 \%$, showed the best performance among all those tested. According to ASTM C1202, these concretes can be considered as being low and very low chloridepermeable after 90 and 180 days curing, respectively. The improvement in resistance to chloride penetration may be related to the refined pore structure of these concretes and their reduced electrical conductivity [25]. What was confirmed by much research [26-28] is that it is due to secondary contributing pozzolanic reaction that the microstructure of concrete becomes more dense. 


\subsection{Accelerated corrosion test}

The accelerated corrosion behavior of steel bars embedded in the concrete specimens was examined by impressing a constant anodic potential. The current required to maintain the fixed potential was plotted against time, and typical curves of corrosion current-versus-time for the 90 day-cured concrete specimens made with CEM I, CEM II/A-P, and CEM II/B-P cement types are illustrated in Fig. 9. As seen from Fig. 9 the current-time curve initially decreases until a time period after which a steady low rate of increase in current was observed, and after a specific time period a rapid increase in current was detected (until failure). A similar variation of the corrosion current with time has also been observed by other researchers $[14,18]$. This curve was utilized to determine the corrosion time of the specimen; when the specimen cracked due to corrosion and the current began increasing sharply. The first visual evidence of corrosion was the appearance of brown stains on the surface of the specimens. Cracking was observed shortly thereafter, and it was associated with a sudden rise in the current.

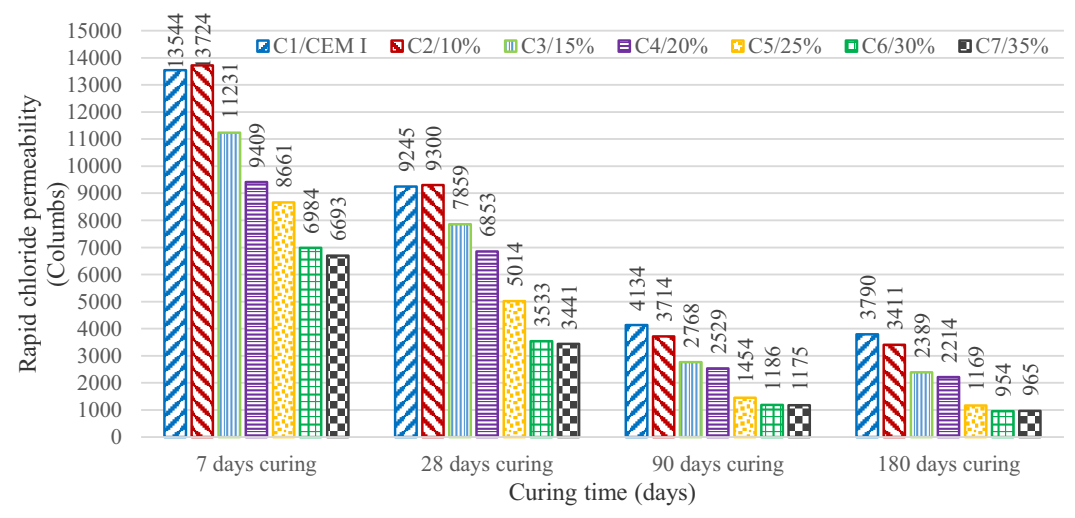

Fig. 8. Total charge passed through concretes (in Coulombs) after 7, 28, 90, and 180 days curing.

Fig. 10 presents the average corrosion initiation times required to crack the specimens made with CEM I, CEM II/A-P, and CEM II/B-P. Time to initiate corrosion in CEM I concrete specimens was in the range of 52-121 h (2-5 days), whereas that in CEM II/B-P was in the range of 83-436 h (3.5-18 days), depending on the replacement level and curing time at testing. The times of corrosion initiation for the scoria-based binder concrete specimens were longer than those for the plain cement concrete specimens, which indicates that the former provided better protection of the steel reinforcements against corrosion.

The best corrosion resistance was obtained from cements with $30 \& 35 \%$ additive ratios. The test lasted 
for $84 \mathrm{~h}, 194 \mathrm{~h}$, and $370 \mathrm{~h}$ in this specimen after 7, 28, and 90 days curing times, respectively. Results also demonstrated that the increase in corrosion initiation times with curing time (from 7, 28, 90, to 180 days) was greater in almost all cases for the scoria-based binder concrete specimens when comparing against the plain concrete specimens. This delay in corrosion time when using scoria-based binders may be related to the pozzolanic reaction of scoria which contributes to the filling of voids and pores in concrete with an additional C-S-H gel. This leads to a decrease of pore size and a smaller effective diffusivity for chloride, which can improve long-term corrosion resistance of reinforced concrete structures and make concrete more dense and less permeable $[18,24]$. Also, it is noted from Figs. $9 \& 10$ that the corrosion resistance of most scoria-based binder concrete specimens increased significantly with age, while that of plain cement concrete had a slight increase only, which has also been indicated by other researchers [18].

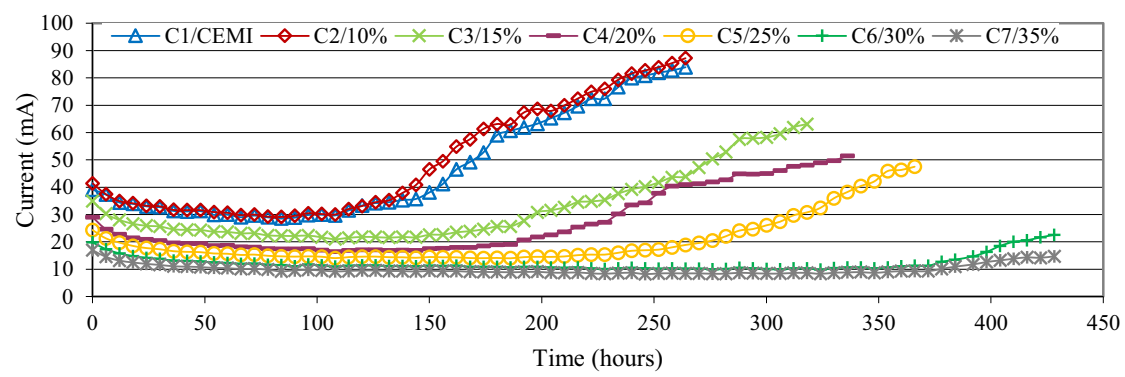

Fig. 9. Typical curves of corrosion current versus time of concrete specimens tested after 90 days curing.

Furthermore, it can be seen in Fig. 11 that the corrosion initiation time and chloride penetrability of concrete are closely related to each other. The analysis results showed an excellent correlation between corrosion initiation time and total charge passed through scoria-based binder concrete specimens, with a regression coefficient $\left(R^{2} \approx 0.96\right)$. According to Montgomery \& Peck [29] a regression coefficient, $R^{2}$, of more than 0.85 indicates an excellent correlation between the fitted parameters. Increasing the total charge passed through the specimens reduces the time required to initiate corrosion.

\subsection{Correlation equation}

The experimental data depicted in Figs. 5-10 has been statistically analyzed to develop an estimation equation able of correlating the performance of concrete with the curing time and the replacement level of volcanic scoria.

The equation can be expressed by the following single formula: 
$P I=a_{1}+a_{2} \times V S+a_{3} \times \ln t+a_{4} \times V S \times \ln t$

Where $P I$ is the performance indicator (i.e., compressive strength, water permeability, porosity, chloride penetrability, and corrosion resistance); $t$ is the curing time; $a_{1}, a_{2}, a_{3}$, and $a_{4}$ are constants.

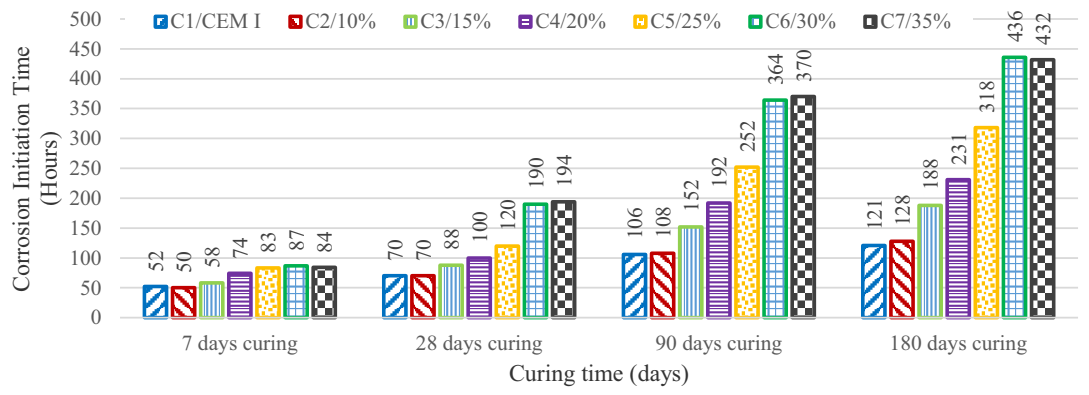

Fig. 10. Comparison of corrosion initiation times of different concretes cured for 7, 28, 90, and 180 days.

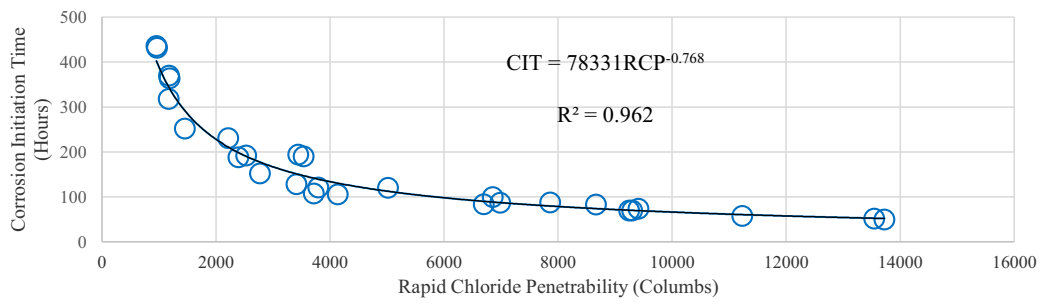

Fig. 11. Variation of corrosion initiation time with rapid chloride penetrability.

The constants have been obtained through the regression analysis of data in Figs. 5-10. The best-fit values of constants $a_{1}, a_{2}, a_{3}$, and $a_{4}$ and the regression coefficients $R^{2}$ of the correlation between the measured and the proposed values are presented in Table 2. The results indicate excellent relationships between the curing times and the performance indicators of concretes with different replacement levels of volcanic scoria.

It is to be noted that the correlation equation developed in this paper would be helpful for concrete mix designers. However, it should be noted that the relationships reported in the paper have been developed for concrete containing limestone aggregates, having $\mathrm{w} / \mathrm{c}$ ratio of 0.6 , and curing at ambient temperatures. Similar relationships may need to be explored for other types of aggregates, different $\mathrm{w} / \mathrm{c}$ ratios, and other curing conditions. From the results obtained, volcanic scoria showed significant improvement in 
performance, which clearly indicates that it is efficient in the refinement of pore size distribution. This has been reflected in the reduction of water permeability, porosity, and chloride penetrability.

Table 2. Constants $a_{1}, a_{2}, a_{3}$, and $a_{4}$ and regression coefficients $\left(R^{2}\right)$ of the correlation between the measured and calculated values according to the proposed equation.

\begin{tabular}{|l|l|l|l|l|l|}
\hline \multirow{2}{*}{ Performance indicator (PI) } & \multicolumn{4}{|c|}{ Constants } & \multirow{2}{*}{ Regression coefficient $\left(R^{2}\right)$} \\
\cline { 2 - 5 } & $a_{1}$ & $a_{2}$ & $a_{3}$ & $a_{4}$ & \\
\hline Compressive strength (MPa) & 14.408 & -31.053 & 6.653 & -2.028 & 0.984 \\
\hline Water permeability (mm) & 192.08 & -153.82 & -30.09 & 16.006 & 0.949 \\
\hline Porosity (\%) & 33.052 & -32.093 & -3.913 & 2.282 & 0.967 \\
\hline Chloride penetrability (Columbs) & 23561 & -41649 & -3889.8 & 6208 & 0.961 \\
\hline Corrosion Initiation Times (Hours) & 67.511 & -634.78 & -17.225 & 382.16 & 0.958 \\
\hline
\end{tabular}

Results have been confirmed using the SEM/EDX techniques, as shown in Figs. $12 \& 13$. The microstructural and EDX analysis of the 7-day cured C6/30\% paste, Fig. 12, reveals a non-compacted structure. On the other hand, after 90 days of curing, the microstructural analysis of the $C 6 / 30 \%$ paste shows denser and more compacted structure due to the progress of cement hydration. In addition, the EDX analysis results clearly indicate the formation of cementitious phases, such as calcium silicate hydrate (C-S-H) and calcium alumino-silicate-hydrates (C-A-S-H). These might be formed through the continuation of cement hydration and the progress of the pozzolanic reaction between the amorphous phases in volcanic scoria and the $\mathrm{CH}$ (calcium hydroxide) released during cement hydration [30].

\section{CONCLUSION}

From these experimental results, the following conclusions can be drawn:

-The compressive strengths of concretes containing scoria-based binders were much lower than those of plain cement concrete at all early ages of concrete. However, after 90 days of curing, the compressive strengths of scoria-based binder concretes were comparable to those of plain cement concrete.

-Water permeability, porosity, and chloride penetrability of scoria-based concrete mixes is much lower than that of plain concrete, especially at longer curing times and high replacement levels of scoria. This has also been confirmed by SEM/EDX analysis.

-According to the results of the accelerated corrosion test, concretes produced with scoria-based binders and cured for 28 days or more decelerated rebar corrosion. Particularly, CEM II/B-P cement types with 25,30 , and $35 \%$ scoria content were found to delay corrosion significantly. The use of scoria at $30 \%$ 
cement replacement levels is extending the service life of the RC structure under chloride-bearing environments twice or thrice, when compared to the control.

-The authors derived an estimation equation for the investigated performance indicators incorporating the effect of curing times and the replacement levels of volcanic scoria. Development of such a positive relationship between the performance indicators and the curing times can be of considerable benefit. However, this relationship is limited only to a w/c ratio of 0.6 .
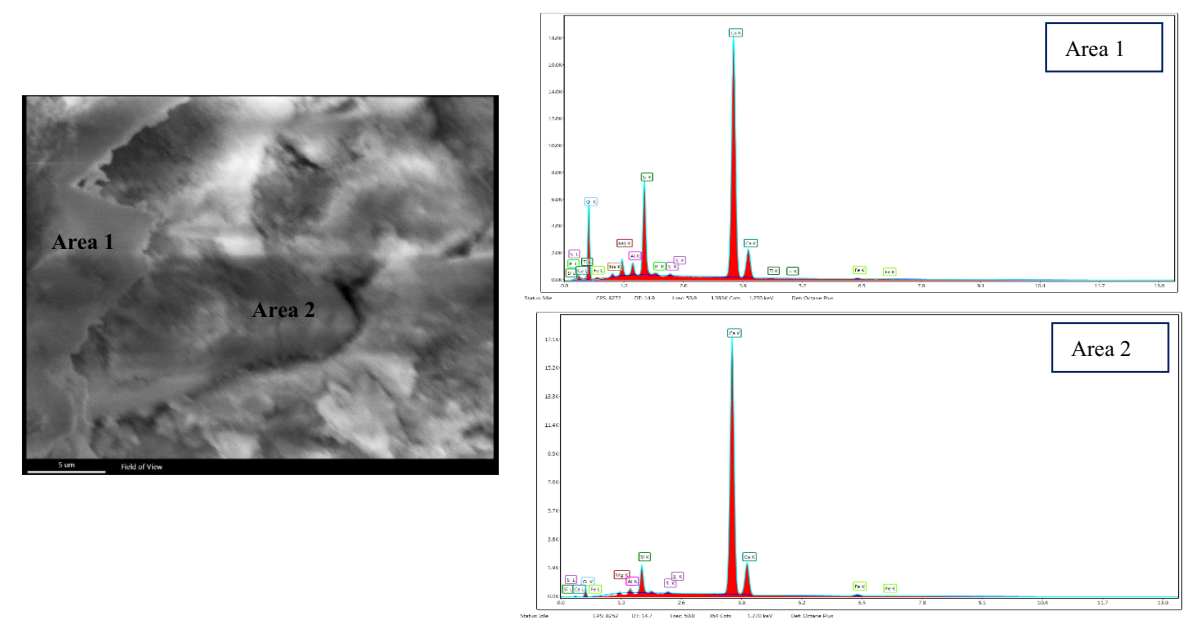

Fig. 12. SEM/EDX analysis of 7-day cured $\mathrm{C} 6 / 30 \%$ paste (magnification $\times 5000$ ) 

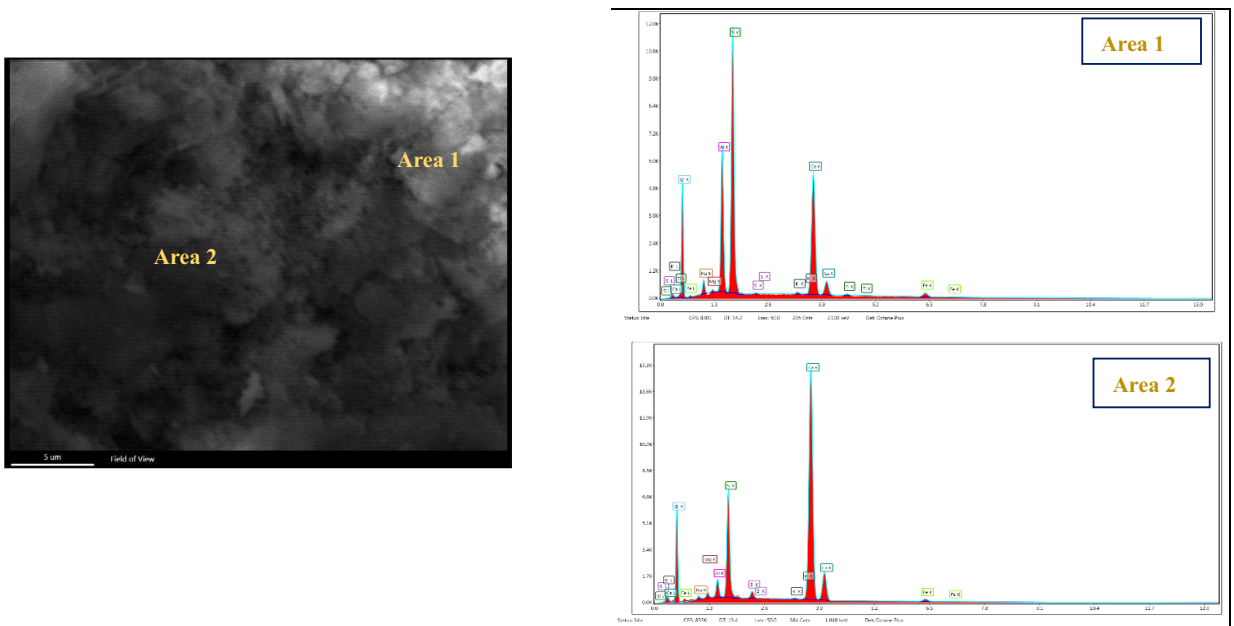

Fig. 13. SEM/EDX analysis of 90 -day cured C6/30\% paste (magnification $\times 5000)$

-Based on the test results, it is suggested that volcanic scoria can be used as a partial substitute for Portland cement in production of blended cements. Depending on the replacement level, it can reduce the quantity of $\mathrm{CO}_{2}$ released by Syrian cement plants and consumed energy at annual rates, and so production of a 'green concrete' could be promoted.

-A definite correlation is observed between the rapid chloride penetrability test and the accelerated corrosion test, such as one can be estimated from knowledge of the other.

-Curing has a large influence on both compressive strengths and durability properties of scoria-based binder concretes. The consequences of bad curing, however, can be more serious for the latter.

-Based on the results obtained, the assumption that 'strong concrete is durable concrete' is not always true. Scoria-based binder concretes had lower compressive strengths, but greater resistance to water and chloride penetration, as well as longer corrosion initiation times compared to plain cement concretes at almost all curing times.

\section{ACKNOWLEDGEMENT}

The authors gratefully acknowledge the technical and financial support of this research from the management of General Organization for Cement \& Building Materials/Adra Cement Plant. Thanks are also expressed to Eng. Amjad Burnieh (Lafarge Co.) and Prof. Tamer al-Hajeh, vice-president of AIU for their appreciated help. 


\section{REFERENCES}

1. G. Al-Chaar, M. Al-Kadi, P. Asteris, "Natural pozzolan as a partial substitute for cement in concrete", The Open Construction and Technology Journal, 7, 33-42, 2013.

2. Y. Senhadji, G. Escadeillas, H. Khelafi, M. Mouli, A. Benosman, "Evaluation of natural pozzolan for use as supplementary cementitious material", European Journal of Environmental and Civil Engineering, 16, 1, 77-96, 2012.

3. K. Hossain, "Resistance of scoria-based blended cement concrete against deterioration and corrosion in mixed sulfate environment", Journal of Materials in Civil Engineering, ASCE, 21, 7, 299-308, 2009.

4. M. Ghrici, S. Kenai, E. Meziane, "Mechanical and durability properties of cement mortar with Algerian natural Pozzolana", Journal of Material Science, 41, 6965-6972, 2006.

5. A. Cavdar, S. Yetgin, "Availability of tuffs from northeast of Turkey as natural pozzolans on cement, some chemical and mechanical relationships", Construction and Building Materials, 21, 2066-2071, 2007.

6. L. Turanli, B. Uzal, F. Bektas, "Effect of large amounts of natural pozzolan addition on properties of blended cements", Cement Concrete Research, 35(6), 1106-1111, 2005

7. R. Rodriguez-Camacho, R. Uribe-Afif, "Importance of using natural pozzolans on concrete durability", Cement and Concrete Research, 32, 1851-1858, 2002.

8. M. Khan, A. Alhozaimy, "Properties of natural pozzolan and its potential utilization in environmental friendly concrete", Can. J. Civ. Eng., 38, 71-78, 2011

9. The General Establishment of Geology and Mineral Resources in Syria (GEGMR) 2011. A Guide for mineral resources in Syria. (in Arabic).

10. The General Establishment of Geology and Mineral Resources in Syria (GEGMR) 2007. Official document nr. (3207/T/9) dated 21.11.2007.(in Arabic).

11. The General Organization for Cement \& Building Materials (GOCBM) 2011. (www.cemsyria.com). Accessed in 2011. 12. A. Neville, "Properties of concrete", Fifth edition, Pearson Education, 2011.

13. X. Shi, N. Xie, K. Fortune, J. Gong, "Durability of steel reinforced concrete in chloride environments, An overview", Construction and Building Materials, 30, 125-138, 2012.

14. V. Horsakulthai, S. Phiuvanna, W. Kaenbud, "Investigation on the corrosion resistance of bagasse-rice husk-wood ash blended cement concrete by impressed voltage", Construction and Building Materials, 25: 54-60, 2011.

15. A. Parande, B. Babu, M. Karthic, K. Kumaar, N. Palaniswamy, "Study on strength and corrosion performance for steel embedded in metakaolin blended concrete/mortar", Construction and Building Materials, 22: 127-134, 2008.

16. T. Ha, S. Muralidharan1, J. Bae, Y. Ha, H. Lee, K. Park, D. Kim, "Accelerated short-term techniques to evaluate the corrosion performance of steel in fly ash blended concrete", Building and Environment, 42, 78-85, 2007.

17. V. Saraswathy, H. Song, "Corrosion performance of rice husk ash blended concrete", Construction and Building Materials, 21, 1779$1784,2007$.

18. E. Guneyisi, T. Ozturan, M. Gesoglu, "A study on reinforcement corrosion and related properties of plain and blended cement concretes under different curing conditions", Cement \& Concrete Composites, 27:, 449-461, 2005.

19. J. Rossignolo, M. Agesini, « Durability of polymer-modified lightweight aggregate concrete », Cement \& Concrete Composites, 26, 4, 357-380, 2004.

20. F. Shaker, A. El-Dieb, M. Reda, "Durability of styrene-bautadiene latex modified concrete", Cement and Concrete Research, 27(5), 7711-7720, 1997.

21. S. Khedr, A. Idriss, "Resistance of silica fume concrete to corrosion-related damage", ASCE, Journal of Materials in Civil Engineering, ASCE, 7, 2, 102-107, 1995.

22. A. Al-Tayyib, M. Al-Zahrani, "Corrosion of steel reinforcement in polypropylene fiber reinforced concrete structures", ACI Materials Journal, 87, 2, 108-113, 1990.

23. P. Mehta, P. Monteiro, "Concrete: Microstructure, properties, and Materials", 3 rd edition, McGraw-Hill, 2006.

24. K. Hossain, "Blended cement using volcanic ash and pumice", Cement and Concrete Research, 33, 1601-1605, 2003.

25. C. Talbot, M. Pigeon, M. Maarchand, J. Hornain, J., "Properties of mortar mixtures containing high amounts of various supplementary cementitious materials", In: Proceeding of the fifth international conference on the use of fly ash, silica fume, slag, and natural pozzolana in Concrete, Edited by Malhotra V.M., Milwaukee, ACI SP, 153, 125-152, 1995.

26. S. Rukzon, P. Chindaprasirt, "Effect of grinding on chemical and physical properties of rice husk ash", Int J Miner Metal Mater, 16, 2, 242-247, 2009.

27. P. Chindaprasirt, C. Chotithanorm, H. Cao, V. "Sirivivatnanon, Influence of fly ash fineness on the chloride penetration of concrete", Construction and Building Materials, 21, 356-361, 2007.

28. A. Gastaldini, G. Isaia, N. Gomes, J. Sperb, "Chloride penetration and carbonation in concrete with rice husk ash and chemical activation", Cement \& Concrete Composites, 21, 356-361, 2007.

29. D. Montgomery, E. Peck, "Introduction to linear regression analysis", New York, Wiley, 1982.

30. S. Mindess, J. Young, D. Darwin, "Concrete", $2^{\text {nd }}$ edition, Prentice Hall, 2003. 


\section{LIST OF FIGURES AND TABLES}

Fig. 1. Map of Harrat Al-Shaam, photos of the studied site and the scoria aggregate utilized.

Rys. 1. Mapa Harrat Al-Shaam, zdjęcia badanego terenu i zastosowanego kruszca scoria.

Fig. 2. Thin sections of the studied scoria.

Rys. 2. Cienkie odcinki scorii.

Fig. 3. Experimental setup of the rapid chloride penetration test.

Rys. 3. Eksperymentalna konfiguracja szybkiego testu przenikalności chlorków.

Fig. 4. Schematic representation \& view of experimental setup for the accelerated corrosion test.

Rys. 4. Schematyczna prezentacja i widok eksperymentalnej konfiguracji dla przyspieszonego badania korozyjnego.

Fig. 5. Compressive strengths of different concretes at 7, 28, 90, and 180 days of curing.

Rys. 5. Wytrzymałość na ściskanie różnych rodzajów betonu przy 7-, 28-, 90- i 180-dniowym utwardzaniu.

Fig. 6. Water penetration depths in different concretes cured for 7, 28, 90, and 180 days.

Rys. 6. Głębokości przenikania wody w różnych rodzajach betonu, utwardzanych przez 7, 28, 90 i 180 dni.

Fig. 7. Porosity of concretes with different levels of volcanic scoria after 7, 28, 90, and 180 days of curing.

Rys. 7. Porowatość betonów o różnych poziomach wulkanicznej scorii, po 7, 28, 90 i 180 dniach utwardzania.

Fig. 8. Total charge passed through concretes (in Coulombs) after 7, 28, 90, and 180 days of curing.

Rys. 8. Całkowity ładunek przechodzący przez betony (w kulombach) po 7, 28, 90 i 180 dniach utwardzania.

Fig. 9. Typical curve of corrosion current versus time of concrete specimens tested after 90 days of curing.

Rys. 9. Typowe krzywe prądu korozyjnego w porównaniu z czasem próbek betonu badanych po 90 dniach utwardzania.

Fig. 10. Comparison of corrosion initiation times of different concretes cured for 7, 28, and 90 days.

Rys. 10. Porównanie czasów rozpoczęcia korozji różnych rodzajów betonu utwardzanych przez 7, 28, 90 i 180 dni.

Fig. 11. Variation of corrosion initiation time with rapid chloride penetrability.

Rys. 11. Zmiana czasu rozpoczęcia korozji przy szybkiej przenikalności chlorków.

Fig. 12. SEM/EDX analysis of 7-day cured $\mathrm{C} 6 / 30 \%$ paste.

Rys. 12. Analiza SEM/EDX pasty C6/30\% utwardzanej przez $7 \mathrm{dni}(\mathrm{w}$ powiększeniu $\times 5000)$.

Fig. 13. SEM/EDX analysis of 90 -day cured $\mathrm{C} 6 / 30 \%$ paste.

Rys. 13. Analiza SEM/EDX pasty C6/30\% utwardzanej przez 90 dni (w powiększeniu $\times 5000$ ).

Table 1. Chemical composition of utilized materials

Tabela 1. Skład chemiczny zastosowanych materiałów

Table 2. Constants $a_{1}, a_{2}, a_{3}$, and $a_{4}$ and regression coefficients $\left(R^{2}\right)$ of the correlation between the measured and calculated values, according to the proposed equation.

Tabela 2. Stałe $a_{1}, a_{2}, a_{3}$ i $a_{4}$ oraz współczynniki regresji $\left(R^{2}\right)$ korelacji mierzonych i obliczonych wartości, zgodnie $\mathrm{z}$ proponowanym równaniem. 


\section{WPLYW CZASU UTWARDZANIA NA WYDAJNOŚĆ BETONU NA BAZIE SCORII WULKANICZNEJ}

Slowa kluczowe: czas utwardzania, przepuszczalność wody, porowatość, przenikalność chlorków, odporność na korozję, cement mieszany, scoria wulkaniczna.

\section{Streszczenie:}

W Syrii znajdują się ważne obszary wulkaniczne o szacowanych rezerwach wynoszących około trzy czwarte miliardów ton wulkanicznej scorii. Jednakże, ich potencjalne zastosowanie w produkcji betonu nie jest powszechnie znane. Powszechnie uznaje się, że jakiekolwiek zwiększenie wydajności konstrukcji żelbetonowych zwiększa stabilność branży budowlanej. Prawdopodobnie jednym z najskuteczniejszych podejść jest zastąpienie pucolanów częścią cementu portlandzkiego. Wytrzymałość betonu jest powszechnie uważana za jego najcenniejszą właściwość, chociaż jego inne właściwości, takie jak trwałość i przepuszczalność, mogą być w rzeczywistości ważniejsze. Obecnie uważa się, że korozja indukowana chlorem jest najpoważniejszym mechanizmem niszczenia konstrukcji żelbetonowych. Korozja stali zbrojeniowej jest istotnym problemem spotykanym w branży budowlanej w Syrii, zwłaszcza w środowiskach przemysłowych i morskich. Wiele konstrukcji żelbetonowych zetknęło się z tym zjawiskiem, co znacząco skróciło ich żywotność. Celem niniejszej pracy jest zbadanie wpływu wykorzystania scorii wulkanicznej jako zamiennika cementu, w odniesieniu do niektórych właściwości użytkowych cementu. W szczególności zbadano wytrzymałość na ściskanie, przepuszczalność wody, porowatość, przenikalność chlorków i odporność na korozję zbrojenia osadzonego w betonie zawierającym cement na bazie scorii, po utwardzaniu przez 7, 28, 90 i 180 dni.

Scoria wulkaniczna wykorzystywana w eksperymentach została wykopana w miejscowości Dirat-at-Tulul, około 70 kilometrów na południowy wschód od Damaszku. Siedem próbek środka wiążącego zostało przygotowanych zgodnie z normą EN 197-1; jeden zwykły cement portlandzki CEM I (kontrola) oraz sześć mieszanych cementów o poziomach wymiany wynoszących od 10 do $35 \%$. Wszystkie próbki zostały rozłożone z dokładnością Blaine'a wynoszącą $3200 \pm 50 \mathrm{~cm} 2 / \mathrm{g}$. CEM I (próbka kontrolna) została oznaczona jako C1/CEM I, podczas, gdy środki wiążące na bazie scorii oznaczono zgodnie z poziomem wymiany. Na przykład, C2/10\% i C7/35\% odnoszą się do środków wiążących zawierających 10\% i 35\% scorii wulkanicznej.

Siedem mieszanek betonowych zostało przygotowanych na podstawie klasyfikacji mieszanek agregatów utrzymywanych na stałym poziomie dla wszystkich mieszanek betonowych $150 \pm 20 \mathrm{~mm}$. Agregaty zastosowane w badaniu obejmowały rozdrobniony dolomit $\mathrm{z}$ dodatkiem naturalnego piasku. Wszystkie mieszanki betonowe zostały stworzone tak, aby ich stosunek wody do cementu wynosił 0,6 , a spadek wynosił $150 \pm 20 \mathrm{~mm}$.

Wytrzymałość na ściskanie została obliczona w oparciu o $150 \mathrm{~mm}$ próbki betonowe, zgodnie z normą ISO 4012, w ciągu 7, 28, 90 i 180 dni. Przepuszczalność betonu, mierzona pod względem głębokości przenikania wody, została zbadana zgodnie z normą EN 12390-8. Pomiary porowatości zostały przeprowadzone przy użyciu metody nasycenia próżniowego, zgodnie z RILEM CPC 11.3. Szybki test przenikalności chlorków (RCP) został przeprowadzony zgodnie z ASTM C 1202. Szybkie badanie korozji zostało przeprowadzone przez zastosowanie stosunkowo wysokiego potencjału anodowego o wartości $12 \mathrm{~V}$, w celu przyspieszenia procesu korozji.

Wytrzymałość na ściskanie betonu wzrosła wraz z czasem utwardzania. Próbki standardowego betonu charakteryzują się wysoką wytrzymałością na ściskanie w każdym wieku, w porównaniu do betonów na bazie scorii. Wynika to z: i) powolności reakcji pucolanowej pomiędzy fazą szklistą w scorii i wodorotlenkiem wapnia uwalnianym podczas uwodnienia cementu oraz ii) efektu rozcieńczania. Jednakże, ze względu na kontynuację reakcji pucolanowej oraz powstawanie wtórnego C-S-H, osiągnięto wyższy stopień uwodnienia, uzyskując wytrzymałości po 90 dniach utwardzania, które były porównywalne z wytrzymałościami próbek CEM I. Wyniki testów przepuszczalności wody wykazały, że żaden z betonów nie był nieprzepuszczalny po 28 dniach utwardzania. Jednakże, wszystkie rodzaje betonów zawierające środki wiążące na bazie scorii można uznać za nieprzepuszczalne po 90 dniach utwardzania. Betony zawierające scorię wulkaniczną wykazały znacznie niższą porowatość w porównaniu do zwykłego betonu. Zmniejszenie porowatości można również przypisać reakcji 
pucolanowej pomiędzy fazą szklistą w scorii wulkanicznej i $\mathrm{CH}$ wyzwolonemu z uwodnienia $\mathrm{C}_{3} \mathrm{~S}_{\text {i }} \mathrm{C}_{2} \mathrm{~S}$.

W trakcie testu przepuszczalności chlorków, beton na bazie CEM I zezwolił na niemal 2 lub 3-krotne przejście ładunku kulombów, w porównaniu do betonu zawierającego CEM II/B, pomimo faktu, że wszystkie betony posiadały podobną zawartość cementu i wody. Po 7 lub 28 dniach utwardzania, żaden z betonów nie zezwolił na przejście mniejszego ładunku niż 2000 kulombów. Jednakże, betony zawierające CEM II/B-P o zawartości scorii wynoszącej 25, 30 i 35\% wykazały się najlepszą wydajnością wśród wszystkich próbek. Betony te można uznać za charakteryzujące się niską lub bardzo niską nieprzepuszczalnością chlorków, po odpowiednio 90 i 180 dniach utwardzania. Ta poprawa odporności na przenikanie chlorków może być związana z udoskonaloną strukturą porów w tych betonach oraz ich zmniejszonym przewodnictwem elektrycznym.

Przyspieszona korozja stalowych prętów osadzonych w próbkach betonu została zbadana przez wytwarzanie stałego potencjału anodowego. Czas rozpoczęcia korozji w próbkach betonu CEM I mieścił się w zakresie od 2 do 5 dni, natomiast w przypadku CEM II/B-P - w zakresie od 3,5 do 18 dni, w zależności od poziomu wymiany oraz czasu utwardzania podczas badania. To opóźnienie w czasie korozji przy zastosowaniu środków wiążących na bazie scorii może być związane z reakcją pucolanową scorii, która przyczynia się do wypełnienia pustych przestrzeni i porów w betonie za pomocą dodatkowego żelu C-S-H. Prowadzi to do zmniejszenia wielkości porów i mniejszej skuteczności dyfuzji chlorku.

$\mathrm{Na}$ podstawie statystycznej analizy wyników badań, autorzy opracowali równanie estymacji w celu skorelowania właściwości betonu z czasem utwardzania oraz poziomem wymiany scorii wulkanicznej. Równanie to można zapisać w następujący sposób: $P I=a_{l}+a_{2} \times V S+$ $a_{3} \times \ln t+a_{4} \times V S \times \ln t$

Gdzie PI jest wskaźnikiem skuteczności (tj. wytrzymałości na ściskanie, przepuszczalności wody, porowatości, przenikalności chlorków i odporności na korozję); $t$ jest czasem utwardzania; $a_{1}, a_{2}, a_{3}$ i $a_{4}$ są stałymi. Współczynnik regresji $\mathrm{R}^{2}$ korelacji między zmierzonymi wartościami a zaproponowanymi wartościami był prawie 0,95 razy większy, co wskazuje na doskonałą korelację pomiędzy dopasowanymi parametrami.

To równanie estymacji mogłoby okazać się pomocne dla projektantów mieszanki betonowej, zawierającej środki wiążące na bazie scorii wulkanicznej. Podobne relacje mogą wymagać opracowania dla innych rodzajów agregatów, różnych stosunków wagowych i innych warunków utwardzania.

Na podstawie uzyskanych wyników, scoria wulkaniczna wykazała znaczną poprawę, co wyraźnie dowodzi faktu, iż scoria wulkaniczna jest skuteczna w ulepszaniu rozkładu wielkości porów. Znajduje to odzwierciedlenie w zmniejszeniu przepuszczalności wody, porowatości, przenikalności chlorków oraz w opóźnieniu w inicjowaniu korozji zbrojenia. Wyniki zostały potwierdzone technikami SEM/EDX, które wskazują na tworzenie faz cementowych, takich jak hydrat krzemianu wapnia (C-S-H) oraz hydraty glinokrzemianu wapnia (C-A-S-H) w późniejszym czasie. Mogłyby one powstać w wyniku kontynuacji hydratacji cementu i postępu w reakcji pucolanowej między fazami amorficznymi w scorii wulkanicznej i CH (wodorotlenkiem wapnia) uwalnianym podczas uwodnienia cementu. 